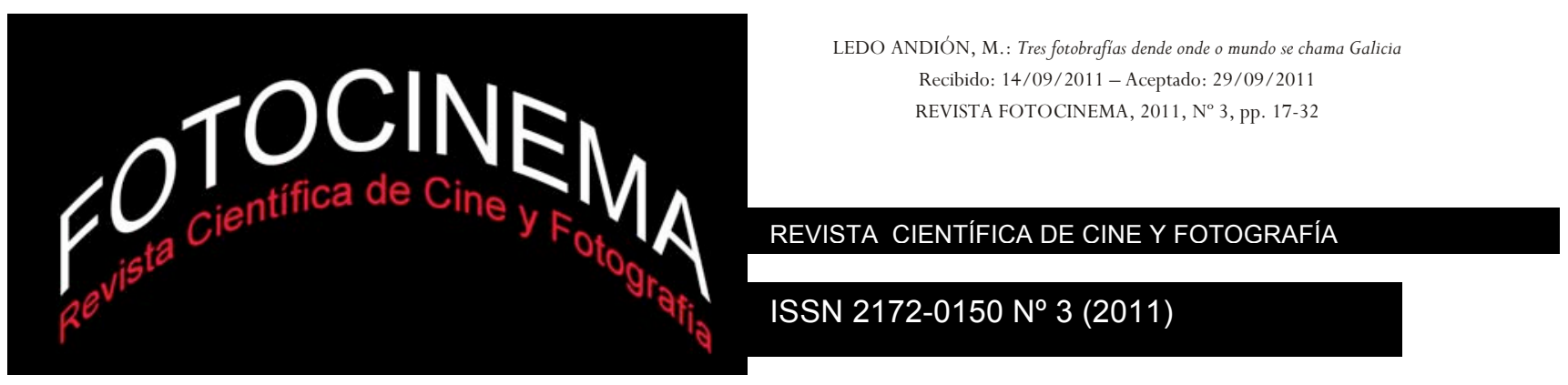

\title{
TRES FOTOBRAFÍAS DENDE ONDE O MUNDO SE CHAMA GALICIA
}

\section{PHOTOGRAPHS FROM WHERE THE WORLD IS CALLED \\ GALICIA}

\author{
Margarita Ledo Andión \\ Universidade de Santiago de Compostela
}

\section{Resumen:}

En "Tres fotografías: dende onde o mundo se chama Galicia”, se trata el papel decisivo que juega la prensa gráfica en la configuración del espacio público, en la idea de ciudadanía y en la construcción del imaginario social a la par de constatar que no son reducibles a la misma categoría de análisis los años de la modernidad que conducen a la Segunda República con los de la dictadura o los de la transición advirtiendo, además, de la desaparición lisa de la foto de prensa como lugar para procesos de connotación y, con ella, la de la cultura del fotoperiodismo.

\begin{abstract}
:
If our main goal is to reconstruct the history of photojournalism in Galicia from the photograph as part of the journalistic discourse, it leads us to confirm some uncertainties that disable a linear story by being unable to construct, much less in the case of a social institution as the press, the period leading to the Second Republic with the long years of dictatorship, nor able to extract a major influence by photographic practices of the early years of political transition in the subsequent configuration of the role of photojournalism in the media enterprises. This article tries to establish an anthropological link between certain images to punctuate the signification of the photographic act and, finally, to highlight the value of the act of viewing, and the photos remembered, those images that among all the other images are ours, and we recover them so that other people love them too.
\end{abstract}

\section{Palabras clave:}

Fotografía; fotoperiodismo; Galicia; imaginario social

\section{Key words:}

Photographia; photojournalism; Galicia; social imaginary 
Fagamos fotos como fotos, esta frase-consigna dun mestre como Paul Strand situaba a fotografía entre os novos obxectos a traveso dos que se ía expresar o século porque nela se xuntan a condición técnica, o real como material e o principio reprodutivo como constitutivo. Eís o origo de pensar a foto como foto de prensa, O que algures sucede precisa do dispositivo e da autoría para devir imaxe fotográfica, e precisa de medios para pasar cara a ollada dunha espectadora, dun espectador que ve o que os outros ven porque existe prensa e que neste acto simple revélase como unha persoa que se sabe co dereito a ver.

Con "Tres fotografías: dende onde o mundo se chama Galicia", quero traer á tona o papel decisivo que xoga a prensa gráfica na configuración do espazo público, na idea de cidadanía e máis na costrución do imaxinario social á par de constatar que non son reducíbeis ás mesmas categorías de análise os anos da modernidade que conducen cara a Segunda República cos da ditadura ou os da transición, advertindo, asemade, doutra desaparición, a da foto de prensa como lugar para procesos de connotación e, a pouco que esculquemos, a da cultura da fotoxornalismo entre nós. Secomasí, dende o interior do discurso xornalístico procurei determinadas fotos e determinados fotógrafos para establecer un vínculo recoñecíbel -e reproducíbel ao longo do tempo- entre certas imaxes e para puntuar a importancia decisiva do acto fotográfico.

Unha outra entrada vén amparada en diferentes épocas da cultura fotográfica: a foto como foto dos vinte-trinta e a atmosfera como fotoxenia; a crenza no momento decisivo, nesa posibilidade de que o material se exprese ao unísono con quen fai a foto, dos cincuenta-sesenta, e a conquista do directo, do imprevisto, de facer corpo co que está sucedendo nos setenta, para chegarmos á distancia xusta, esa nova esixencia. Máis a ollada de meu, as fotos que por motivos diversos, persoais ou comunais, quero amosar no desexo liso de as ver canda os mais.

\section{Pequena intrahistoria xeral}

Coma en calquera país europeo, a modernidade en Galicia ten un dos seus indicadores máis diáfanos na prensa e ten na fotografía unha das súas chaves discursivas sobranceiras. Coma noutros moitos países europeos, o paso do dezanove o vinte non soamente trouxo unha figura nova, a do escritor metido 
a xornalista, como a materialización das condicións que permiten enxergar os periódicos como empresas modernas e singularizar dentro do xornalismo outras profesións, neste caso a de fotoxornalista.

A prensa, suxeito na historia, entrenza cun proceso -relativo- de urbanización, idea igualitaria, alfabetización, aumento do poder adquisitivo e do tempo de lecer, para alén dunha nova concepción empresarial e profesional á que lle cómpren planteis estábeis, certa especialización, desenvolvemento dos xéneros xornalísticos, a foto e a publicidade, o desenrolo das artes gráficas e das asociacións - a Asociación da Prensa da Coruña comeza a campaña contra da censura- e a construción dun público como obxectivo central.

\section{Foto como res pública}

Un xénero coma o retrato e unha foto-noticia; unha revista gráfica, Vida Gallega, e un diario El Pueblo Gallego ${ }^{1}$; Un fotógrafo de estirpe, con estudo en Vigo e con servizo para os principais periódicos, Jaime Pacheco, e un fotógrafo vilego, Pepe Saez, con estudo e con servizos ocasionais de prensa, conformarían a paisaxe estándar da profesión, cun pé no comercial e outro no mediático e son o limiar que nos levará á análise das 3 fotografías.

Partimos do previsto, dun feito de axenda que, por historia, acollerá un significado especial. A foto da chegada da volta ciclista, o plano aberto que mete dentro a quen olla para ela, ese corpo en contacto con outros corpos de idades iguais e diferentes que ollan cara cámara, que sorrín cara outros, os lectores, e para si propios como lectores, é en si mesma un xesto social e a representación da foto como res pública, como cidadanía en construción, como programa democrático, coma o próximo fabulado.

A intención didáctica da información sobre o deporte e o seu tratamento fotográfico nun encadre máis achegado que o común, connotan nesa cativa

\footnotetext{
${ }^{1}$ El Pueblo Gallego, Vigo, 1924-1936 es, canda o periódico Galicia (Vigo, 1922-1926), o modelo de prensa republicana, galega e moderna, onde a imaxe e a opinión son espazos para a diferenza, para crear un público. En 1934, cando o Partido Galeguista decídese por unha "liña de masas" "pensa nun diario. Segundo o historiador Xavier Castro ( $O$ Galeguismo na encrucijada republicana, TD, USC, 1982), Alexandre Bóveda [secretario de organización, fusilado na Caeira, Pontevedra] tería elaborado un proxecto de adquisición do xornal de Portela Valladares, proxecto aprobado polo Consello Nazonal en setembro de 1934, a partires da creación dun accionariado que incluiría a vascos e catalán, republicanos autonomistas máis afiliados e amigos do PG.
} 
variante de linguaxe, o heroe a imitar. Un heroe que ven de pasar traballos pero que chega ata o remate e que é gabado. Un heroe que podes tocar ao alongar a man.

O espazo que toda foto de prensa crea, o intervalo entre a foto e quen olla para ela, neste caso é de total empatía. Trátase dunha foto que todos e todas estamos en condicións de deixar pasar porque ponnos en relación co gañador como parte dun corpo máis extenso e diverso, o corpo social.

Na compaxinación, a foto de Cardona, o vencedor da primeira volta ciclista a Galiza - concreta o pé da fotografía, datado na vila de Ribadeo en 1933- forma díptico con outra imaxe, de plano un chisco máis aberto, tamén de grupo ollando a cámara e ollando ao fotógrafo, mirándonos a nós que ocupamos o lugar do fotógrafo [Pepe Sáez], que nos presenta a Luciano Montero, que fixo na carreira un papel sobranceiro -texto literal tamén ao pé-, creando entre as dúas fotografías unha transferencia, un campo en partilla que se espalla ao suxeito que olla en que sabe que ve o que ven os mais, unha imaxe tamén en partilla.

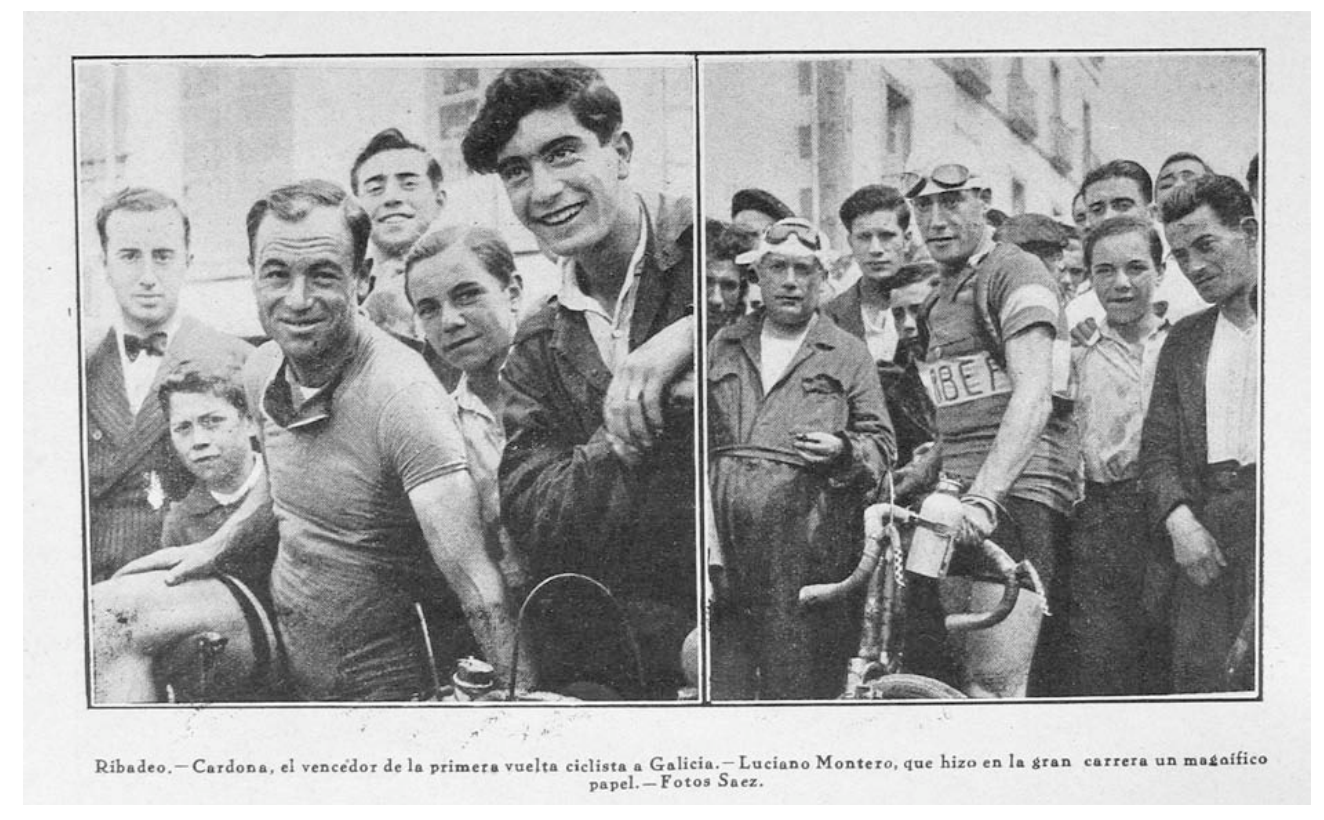

Pepe Sáez, en Vida Gallega

A segunda fotografía non é de acontecemento nin ten como escenario o espazo público. É unha fotografía de portas a dentro, posada, construída a partires da notación que só a atmosfera, como figura criativa, é quen de revelar e que ten 
atrás a ollada dun dos grandes produtores de imaxes da época, Jaime Pacheco e compañía.

O retrato de Alfonso Castelao publicase o 3 de outubro de 1926, domingo, na páxina un de El Pueblo Gallego, para dicirnos que o político, escritor e debuxante [que levara a viñeta de atualidade para a páxina un do Galicia] incorporase, con outro insigne petrucio do galeguismo, don Ramón Otero Pedrayo, ao plantel de colaboradores do diario.

A cámara e o fotógrafo son, neste caso, só mediadores entre a posibilidade única de que se labre unha convención comunicativa a traveso da fotoxenia, iso que soamente existe na fotografía, ese espazo que que habitan a persoa da foto e a que mira para ela, e que fai que ela, que el, vexan xusto o que se lles dá a ver . O primeiro plano, a alma da foto, en que transfire o máis inmaterial do seu modelo, o plano que atravesa a aparencia para fixar, nun plano en se abrindo, lixeiramente picado, coa luz concentrada na faciana e nos ollos -con óculos, o seu particular signo de distinción- a atitude dun Castelao que ergue un case que ren a súa ollada cara o outro, cara o seu espectador-modelo.

E é nese intervalo, nese camiño de ir e vir, onde a connotación da pose e da tecnoestrutura fotográfica -a iluminación, ese lene flou que converte a personaxe nun ser con ás- outórganlle ao retrato de Castelao un valor simbólico na lizgaira inclinación do corpo cara fóra do cadro, cara nós, o contracampo, reforza o espazo, o "ar" que Pacheco converte nunha masa tonal fosca, nun fondo que se nos fai antigo e profundo, encol o que, en fin, a figura ábrese paso cara a tona.

Pero a penas una década despois a historia quebrou.

As condicións para a fotoxornalismo, para esa foto pensada para a prensa e dende unhas regras que o discurso periodístico tiña convertido en máis ou menos estábeis, desaparecen. E canda elas, esa trama específica de tempo e lugar que se establece entre o xornal, a autoría e un público que quere votar. En diante as ordes apuntan a que só se realice aquela fotografía que o poder golpista decida, a que só exista o que o poder golpista deixe con vida. 


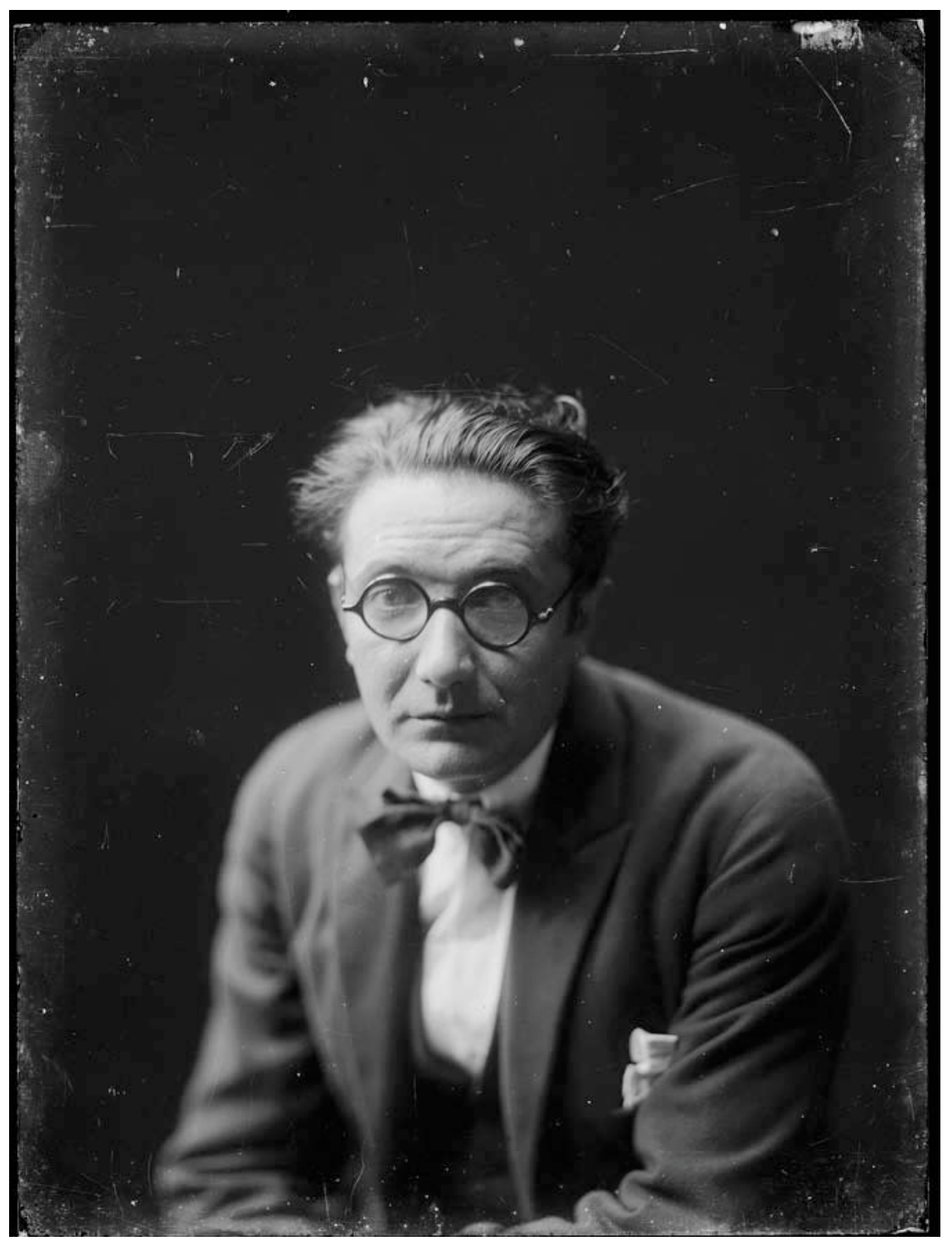

Castelao, por Pacheco, en El Pueblo Gallego

Mais a modo de rastro luminoso desa profesión que medrou na idea de cidadanía, resta un negativo; quédanos unha pegada que o poder ignora, un lugar onde o poder non consegue acceder, e queda unha folla escrita para nos dicir todo o que no podemos ver nesa imaxe que, como ningunha outra na Galiza, pon en primeiro plano o valor indicial, a inscripción do real encol a película, a constatación de que o que se impregna nas sales de prata realmente pasou. 
Réstanos unha foto clandestina e moi pouco nítida da execución dun grupo de militares sublevados contra Franco en outubro de 1936 n’A Coruña; réstanos a foto que dispara un vixía dende a súa garita, e que agacha máis de cincuenta anos. O soldado-vixía que está alerta e que ten canda el, nun recuncho, unha cámara chámase Pepe Sáez, aquel fotógrafo de Ribadeo a quen pertencen as abraiantes imaxes da primeira volta ciclista. El mesmo, en 1988, entrégalle a fotografía ao escritor e dramaturgo Daniel Cortezón, para que esta imaxe comece a procurar un receptor disposto a deixala pasar. A partires de aí a súa viaxe cara o nós adormece deica que Isaac Díaz Pardo faina aparecer no memorial aos fusilados no Campo da Rata. Alí ficou en 2001 esta imaxe que converte en ontolóxico o acto fotografico.

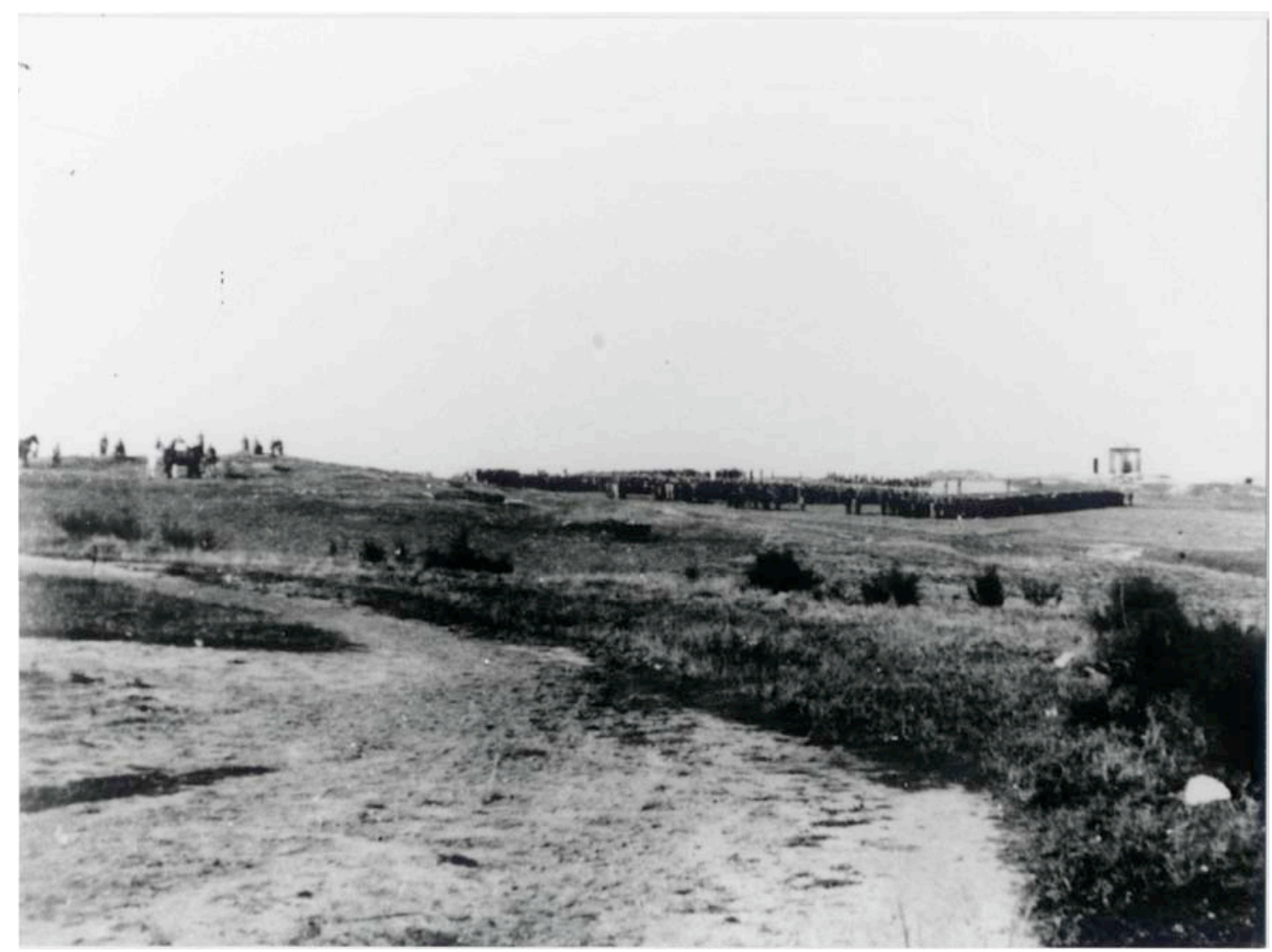

Execucións no Campo da Rata, Pepe Sáez 


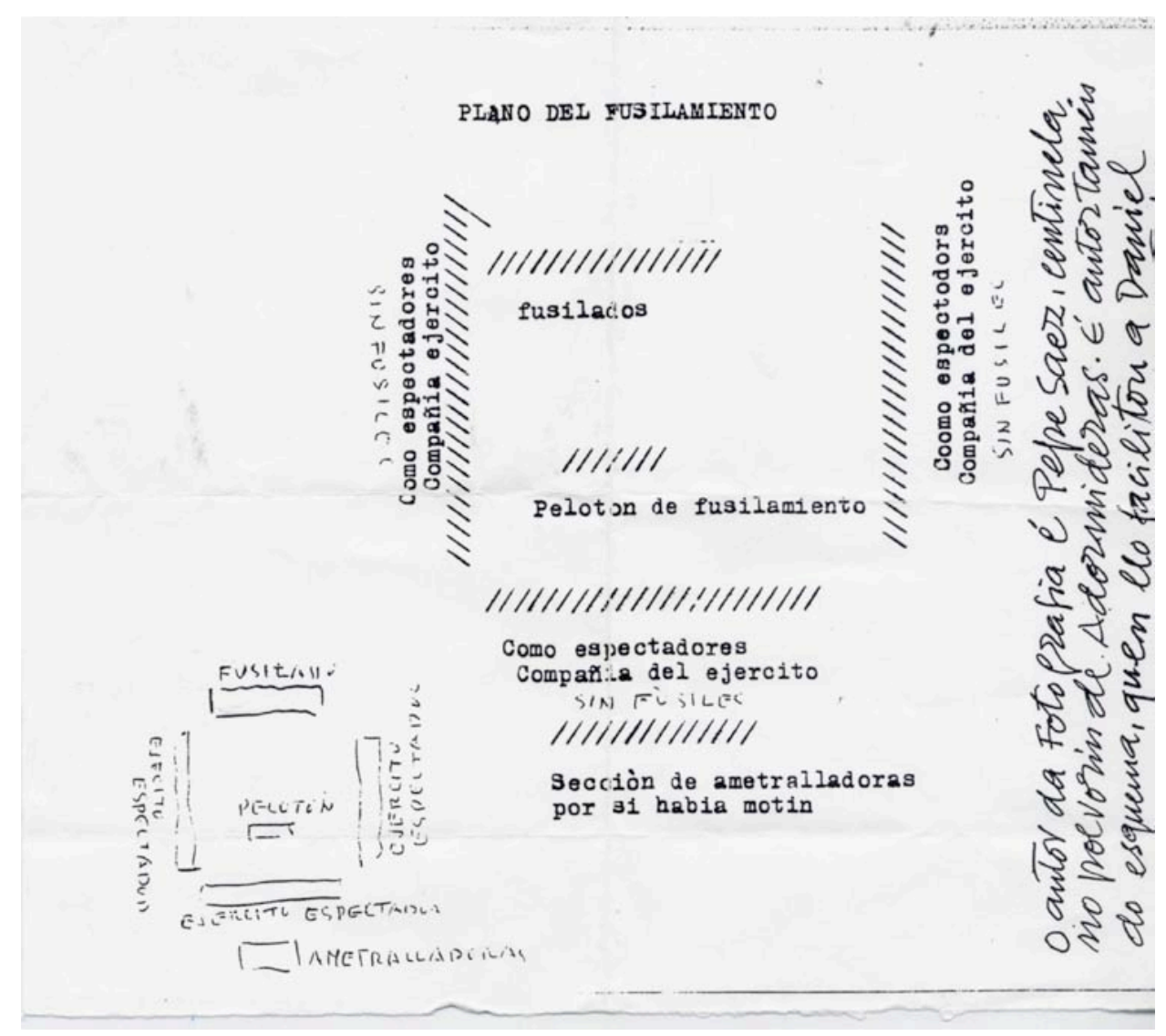

Plano da execución realizado polo propio fotógrafo

E dende este pasado imos ao encontro de tres fotografías

\section{Emigración, poema triste de Galiza}

Si unha soa imaxe pode representarnos como colectivo dentro e fóra, na Galiza e no mundo que non se chama Galiza, esta imaxe é unha imaxe de perda. Si existe unha fotografía na que, outra volta, a atmosfera sexa quen estableza ese nexo invisíbel entre o campo, o fóra de campo que a nosa imaxinación completa, e un contracampo no que, a pesar dos pesares, estamos, si unha única foto é capaz de suspender un ato de fala, esa foto é a de Pai e Fillo, 1957, de Manuel Ferrol. 


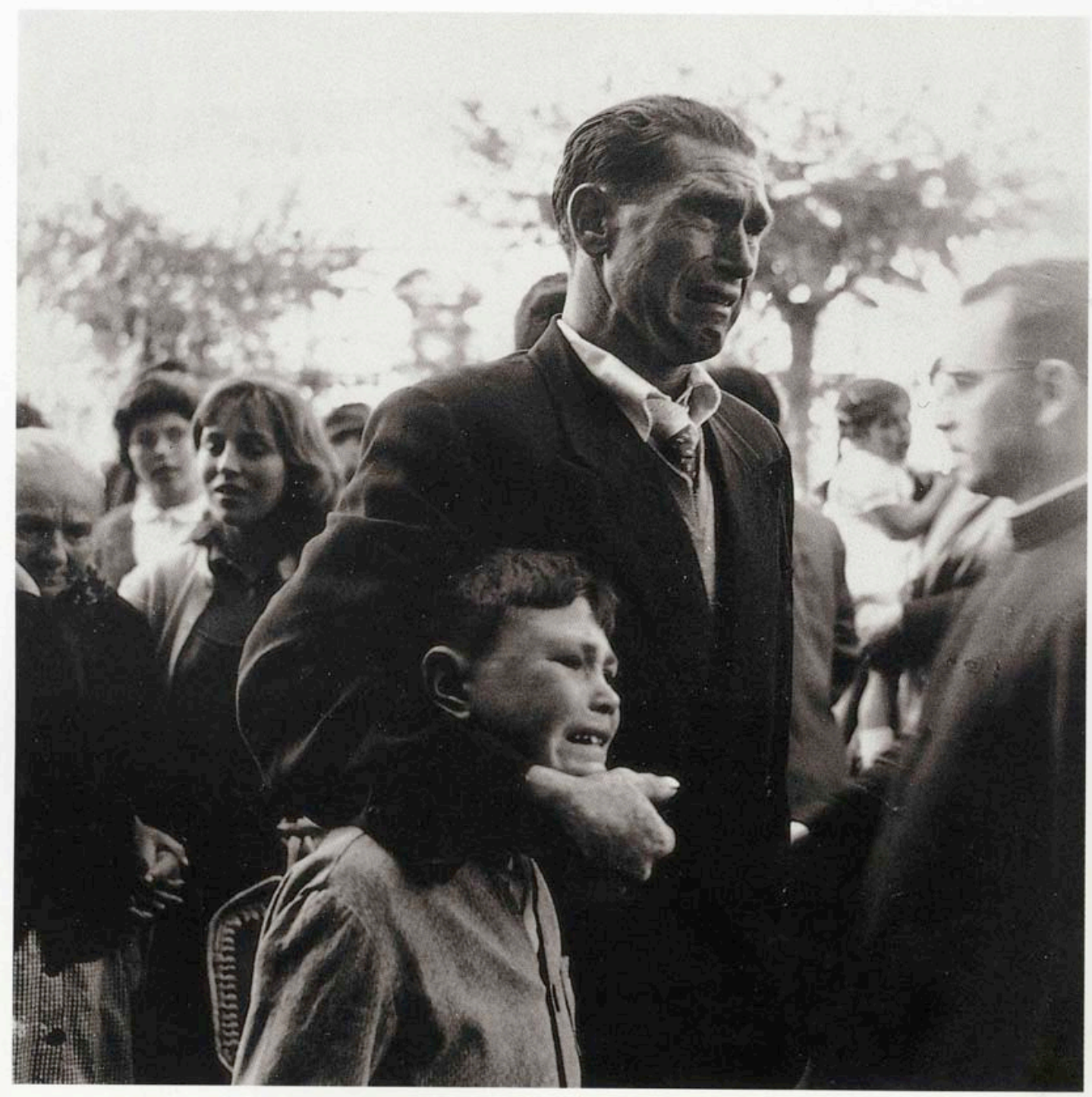

Emigración, de Manuel Ferrol

Fronte da propaganda oficial, fronte a "facer as Américas", fronte a foto "salonista" que louva a molicie un habitante dos Faros, nacido no de Cabo Vilao en 1923, unha personaxe de fronteira, entre mar e terra -que vai percorrendo a Illa de Ons, Cabo Silleiro ou Sálvora-, que coñece o valor do instante e as tempestades, confrontase coa emigración como perda abismal, como fotografía con rostro, como fotografía da dor e coa expresión anti-clixé desa dor: os nenos choran, os homes teñen dereito a chorar.

Acostumado á morte, "a miña nai ficaba sen lenzos para que valeran de mortalla nos naufraxios”, este estudiante de náutica que se achega á fotografía como afeccionado e que nunha exposición de Pla i Janini deixase levar polo fotógrafo 
Juan Cascuera para deixalo todo e facerse retratista, é Manuel Ferrol, arquetipo da mentalidade do novo reporter dos anos cincuenta que influído polo cinematógrafo -el propio será operador de NO-DO dende o 1965-, procura o movemento na foto e procura a secuencia, a historia de principio a fin, como cerna do acto fotográfico. A observación, a chamada a plano do indicio e a espera do imaxinista pegado ao seu obxecto, á súa escena -porque Manuel Ferrol é un home de "escena"-, será entendida como a posibilidade de que se produza o instante que xa se coñece como decisivo.

Quizais por iso os organizadores da exposición Europa de posguerra 19451965. Arte después del diluvio ${ }^{2}$, cincuenta anos despois da fin da segunda gran guerra europea, busquen na serie de Manuel Ferrol esa dobre viaxe, dende hoxe cara o que pasou e atopen nela os ecos do ventre do século.

Unha e outra vez Manuel Ferrol fotografou os portos ou fixo a travesía A Coruña-Vigo para sentir cómo, xusto ao zarpar, o trasatlántico convertese nun buque fantasma: ¿qué pasa con todos os prantos, coa algarabía da despedida, por qué todo devén ese silenzo sepulcral? A encárrega que lle fai a Comisión Católica de Emigración para ilustrar unha campaña de reagrupamento familiar, pono diante a disxuntiva de ficar coas "autoridades" eclesiásticas e do Instituto español de emigración, repite, ou entrar no espazo de "aquela xente que ía e viña como aqueloutrada e que só reacciona cando soa a buguina anunciando a hora da verdade, que un fica mentres outro se alonxa, sen máis”.

Poema triste de América, esta frase coa que Kerouac define o traballo do seu compañeiro de viaxe Robert Frank, nos USA da guerra fría, para ofrecernos a obra, tamén, e na mesma época, é o poema triste e frío dunha Galiza onde é imposíbel a fotoxornalismo. Porén fica a cámara e fica un ensaio que racha cos cánones, para que consigamos termar xuntos da perda. Os encadres inestábeis, sen foco, a súa intensidade evocadora, o ritmo da secuencia deixa en nós o sinal do cineasta que Manuel Ferrol non chegou a ser pero que alimentou nas súas colaboras furtivas con Val del Omar, ou con documentalistas como Antonio Román e Jorge Prelorán.

\footnotetext{
${ }^{2}$ Fundació La Caixa, en coprodución co Ministerio de Educación e Asuntos Culturais de Austria, 1995 
A estrutura narrativa que Manuel Ferrol desenvolve de xeito natural nesa reportaxe reaparece nos seus traballos posteriores máis significados. Do grande plano xeral -que inclúe ao fotógrafo que fotografía- deica chegar ao plano de detalle e retornar, pouco a pouco, cara un plano aberto, de saída, onde xa ninguén produce imaxes como recordatorio e onde o que se nos anuncia, simplesmente, é a ferida.

Preocupado pola desaparición, púxonos nas mans esta vista aérea, esta fotografía topográfica, na que se ve a capeliña na que casou Castelao, comenta. Un lugar que, por suposto, a especulación derribou e que o afán de acabar cos lugares da memoria arbitrou. Pero tampouco eles contaban co rastro do que algures si que estivo aí e que recuperamos nunha das moitas imaxes descoñecidas de Ferrol

Unha foto que pasa á experiencia é, seguramente, unha desas raras imaxes que soamente podemos ver xuntos 3 porque, ao mesmo tempo, é o compendio dunha realidade que nos configura e nos anima a situar a nosa ollada en liña coa que

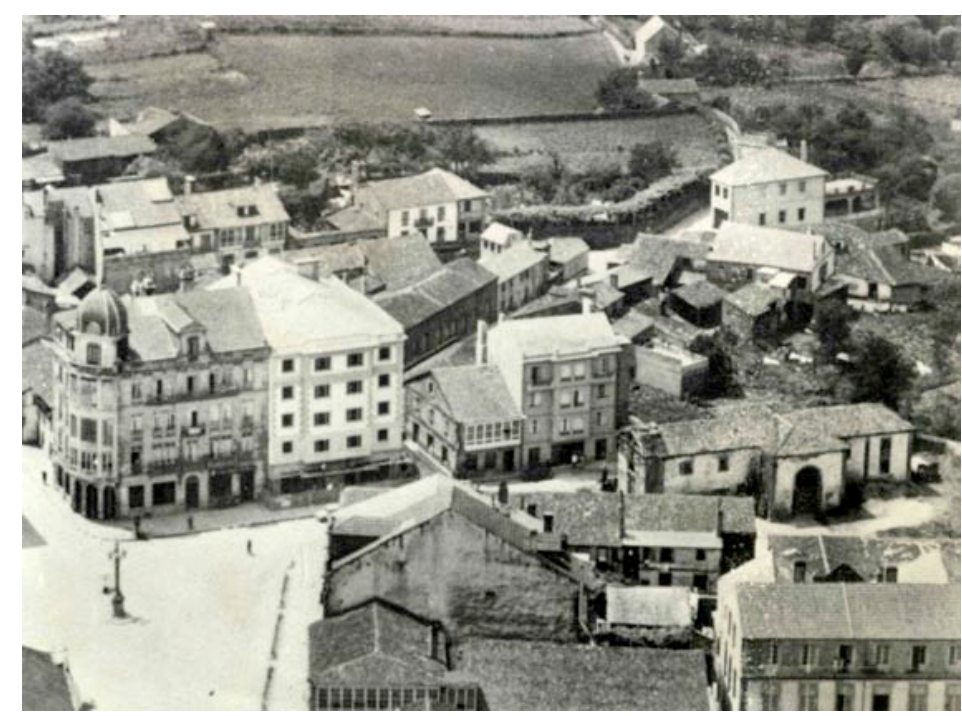

Capela en A Estrada, Manolo Ferrol pai e fillo dirixen cara a sombra do buque pantasma. Unha foto que nos aprende a chorar xuntos, sen necesidade de verter una bágoa, e a saber que o poder é quen ten potestade encol esta escena e sobre o nós carnal co que o poder compón a escena.

\footnotetext{
${ }^{3}<<$ Voir ensemble $>>$, o texto dunha conferencia de Jean-Toussaint Desanti,(2001) convertido en motivo dun encontro organizado, con lectores de diferentes orixes, por Maríe José Mondzain, é para mi un texto de cabeceira, ao que sempre regreso, e co que vou aprendendo matices como este: Chacun voit. Et le voir común n'est pas simplement la convergente d'un regard de Chacón. Il est la production de cet espace commun, où va se constituer l'unité du visible et de l' invisible dans l'oeuvre
} 
Dende ese mesmo ano, 1957,4 Manuel Ferrol vai publicando as súas fotos na prensa mentres fai incursións en diferentes películas. A derradeira das súas aparicións foi na miña primeira longametraxe, Santa Liberdade, e no seu papel de reporter da chegada a Vigo, dende Venezuela, da pasaxe do "Santa María", ocupado durante 13 días por un comando do Directorio Revolucionario Ibérico de Liberación, DRIL, o 21 de xaneiro de 1961, para chamar a atención contra das dictaduras de Franco e Salazar. O seu relato, cunha abraiante foto de indiano que descende do barco portando un paxariño nunha gaiola, publícase nas páxinas do diario El Ideal Gallego. No proemio de Santa Liberdade Ferrol bríndanos a posibilidade de volver situar o transatlántico na ría, retallándoo dun almanaque e reproducindo o truco que fixera nos cincuenta para a película Camarote de Lujo de Rafael Gil. E con este último agasallo, tamén el se alonxou.

Fican os seus sete mil negativos e fica esa foto que tira de outras fotos; queda esa foto que dende o libro de resistencia Galicia Hoy, publicado en 1966 por Ruedo Ibérico, deica a Historia da Fotografía de Beaumont Newhall, parte do porto da Coruña un 27 de novembro de 1957 e segue, a día de hoxe, a amplar a capacidade analítica do noso ollar: ¿por qué lembramos esta imaxe e non outra? ¿por qué queremos lembrar esta imaxe? E así, desta maneira, a nosa memoria se destapa como memoria mediada pola fotografía, como memoria traballada por certas imaxes transitivas.

\section{Vinte anos despois, apareceu outra fotografía}

Tiñamos estado tanto tempo sen a posibilidade de imaxe colectiva nos Medios que a aparición dunha fotografía directa sobre o conflicto que desencadea una orde de expropiación de terras a beneficio da empresa Lignitos de Meirama/FENOSA será, en diante, a que represente o agrarismo en Galiza, a confrontación social co Poder e o retorno da fotoxornalismo á prensa: Xosé Castro, As Encrobas, 1977.

De todas as que realiza Castro, son escasas as fotos publicadas no seu momento, escasas e polo xeral cativas, porque e editor escolmará aquelas en que a acción

\footnotetext{
${ }^{4}$ Anque en múltiples ocasións aparece como data 1956, e eu propia teño unha foto adicada de Ferrol con esa referencia, na documentación última que preparou para a súa exposición no Quiosco Alfonso da Coruña múdaa por 1957.
} 
central a penas apareza. Porén o real vai máis aló, e a foto que expresa ese cruzamento co pasado materializase nesta toma descentrada, con todos os protagonistas en campo, construída dende as pautas da foto informativa e do "estábamos alí" de maneira lisa. E para a persoa que mira a foto publicada na prensa, esta imaxe convertese nun símbolo de todo o que tivo que permanecer ausente.

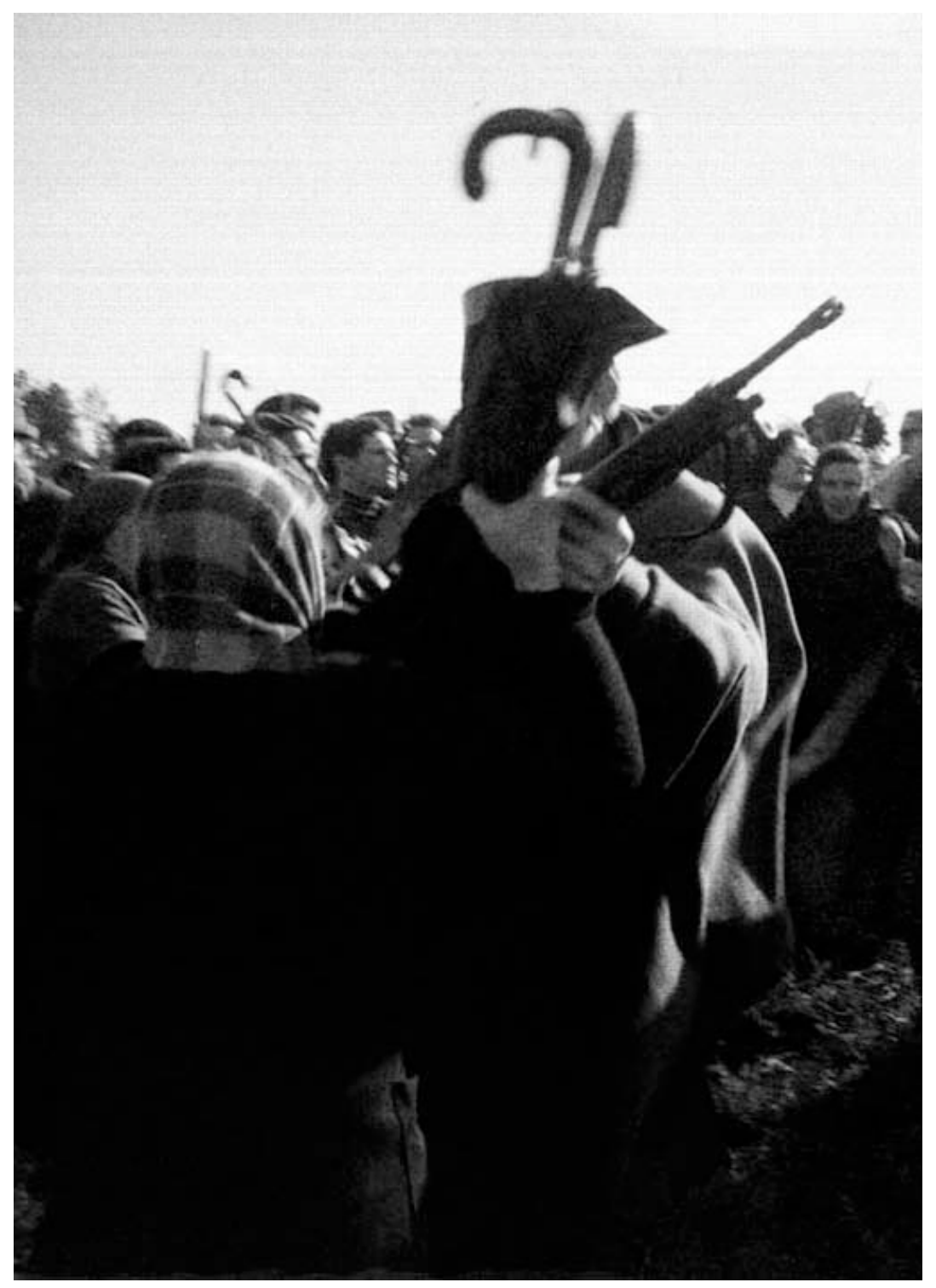

As Encrobas, 1977, Xosé Castro

A maior abondamento, esta fotografía é aquela que nos trae non só a historia do movemento agrario se non o espazo, a terra, e a función protectora da nai, a naiciña, que agora é unha peza activa que ten de se confrontar cos seus propios fillos para, ao facelo, liberalos tamén a eles. 
O ritmo interno da foto, o grao de improviso, a connotación dos obxectos e da roupa -o pano fronte ao tricornio, a chaqueta de punto contra o capote do garda civil, o paraugas gasto e o mosquetón recuando-, as diferencias de idade e de xénero, son parte dos elementos que tamén fan interminábel a ollada analítica neste documento.

Nela as mulleres personifican o elemento colectivo e tamén a persoa que se sabe sen dereitos pero con dereito a ter dereitos: a cidadanía nas súas orixes, o republicanismo primordial. E tal vez por iso quen a mirou non a puido esquecer.

Neno de recados dende os 13 anos na empresa Foto Blanco - a sinatura que nos eu día acompañou estas fotografías-, Xosé Castro formase entre carretes, tira a sua primeira foto cunha Catababy de plástico feita en Catalunya, comenta, e ródase "na foto que te deixan facer". Dende os anos sesenta as súas fotos van cubrindo, día a día, noticias en La Voz de Galicia anque deica 1986 non pasa ser, oficialmente, redactor gráfico de plantilla.

No seu álbum persoal unha escena de 1962, en Bustos, que trae na lenda a dobre codificación do real: Nenos, niños e ovos. E na fotoxornalismo feita na Galiza, a mestría da reportaxe de conflictos que, máis avante volveríamos ver nas súas fotos do desaloxo de caseiros en Larín. As leis do directo, dende dentro do máis incerto, dos feitos no mesmo momento no que se producen, sen capacidade de intervir nin de agardar, son as que moven os fíos do seu obxectivo.

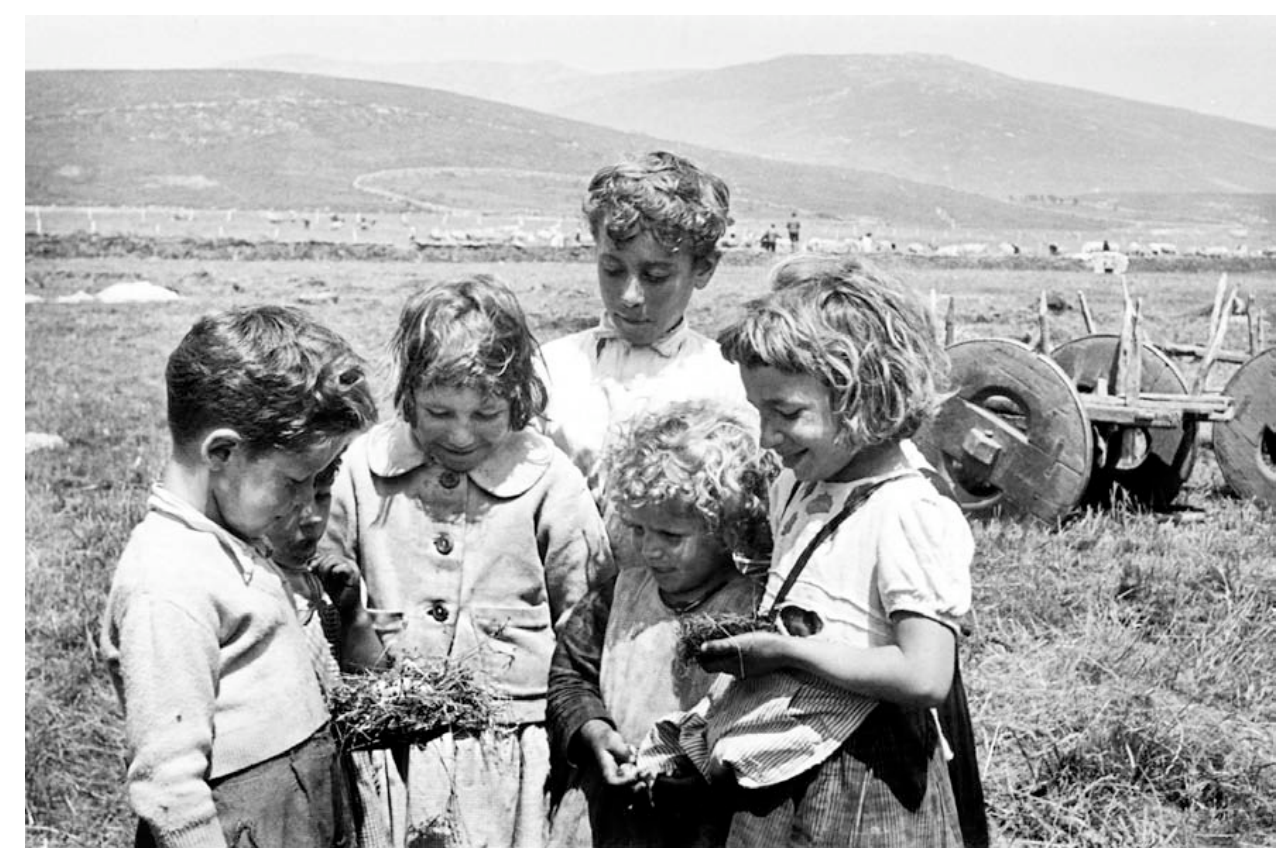

Nenos, niños e ovos, Xosé Castro, 1962 
Tamén na fin do setenta e sete aparecía una cabeceira, A Nosa Terra, 5 que recuperaba a que fora órgano do Partido Galeguista, transformándoa nun periódico semanal. A súa achega singular á fotoxornalismo da Transición abrangue temáticas que formaban parte do non representábel (persoas con trastornos mentais, presos comúns, folgas xerais e outros asuntos á marxe), que pasan a conformar o novo que irrompe (dereitos persoais como a opción sexual, o aborto, o divorcio) e por riba de todo, que lle buscan a faciana ao Poder. Entre outras aparicións $A$ Nosa Terra conta con fotógrafos no cadro de redacción e ata 1980 Fernando Bellas -hoxe cámara de televisión e fotógrafo solidario- será o reporter de continuidade. Todo o que se pode facer co dispositivo canto a punto de vista, angulación e cadro toma corpo neste bodegón enfático da toma de pose do designado presidente Quiroga á cabeza da Xunta Pre-Autonómica, portada do número 64 de $A$ Nosa Terra (1 de xullo de 1979) e que segue a ser, arestora, unha das poucas fotografías que se sitúan nesa distancia xusta e irónica dun Poder que, tamén entre a profesión, contaba coa súa corte ben fidel.

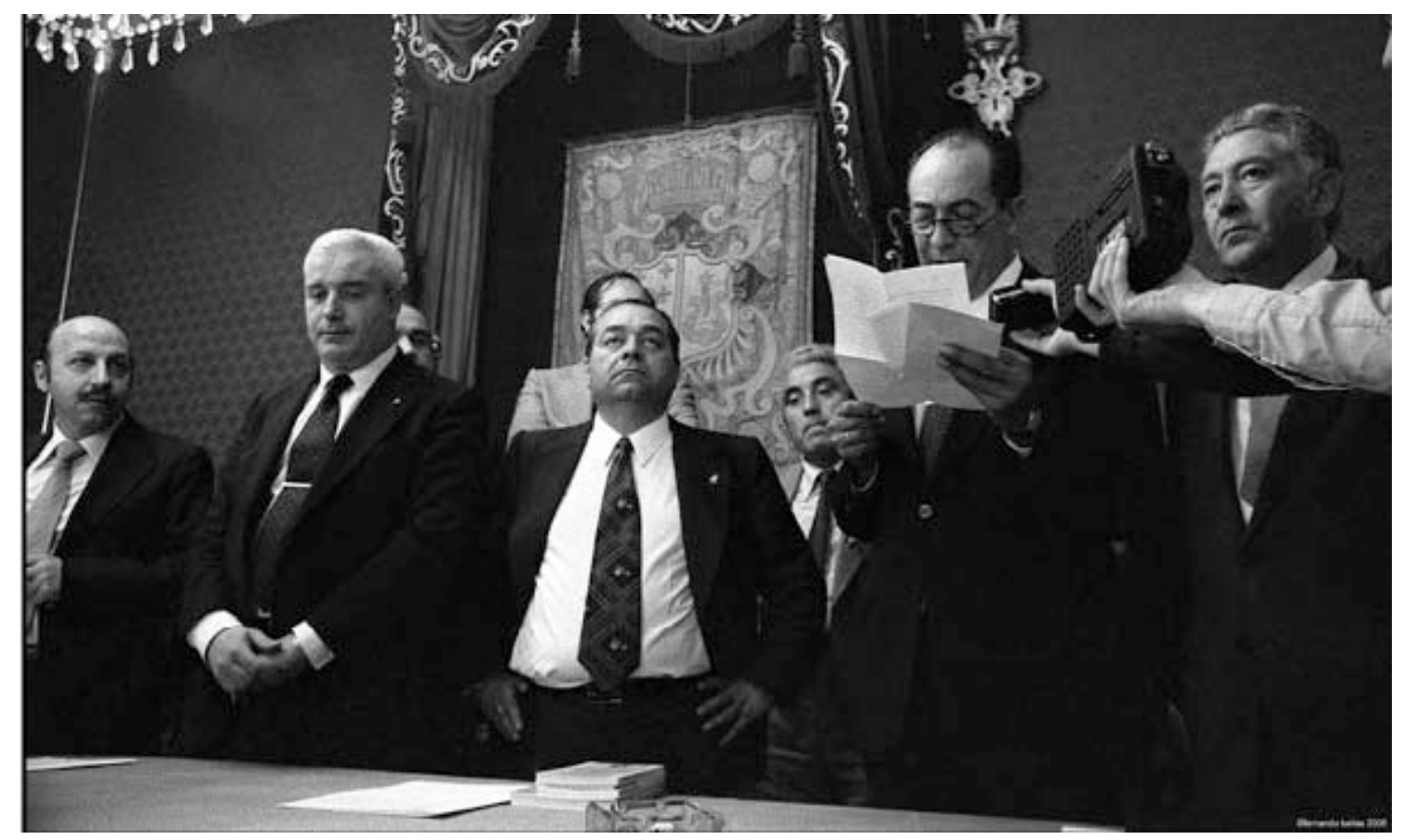

Toma de posesión, Fernando Bellas, A Nosa Terra

\footnotetext{
${ }^{5}$ A Nosa Terra, periódico galego semanal, presentase en decembro de 1977. Fun autora do proxecto, a súa directora deica novembro de 1980 e tivemos a experiencia dun xuízo de intención exemplarizante e inquisitorial, a raíz dunha foto de Fernando Bellas, publicada en portada. Co título "O pan da marxinación" e unha imaxe de Miliqui, o tolo habitual da praza Cervantes, vestido cun viso e co pene ao ar, esculcábase na consideración institucional e social cara as persoas mancadas por trastornos mentais. En simultáneo, as revistas de destape exhibían "as partes íntimas" do corpo, só que no seu caso do corpo feminino. A sentenza foia o noso favor.
} 
Se os fotógrafos viaxeiros que chegan de fóra, coma Ruth Matilde Anderson, 1924, afánanse en anotar a nosa diferenza; se os fotógrafos de dentro, coma Chicharro, retrátannos en plano frontal e simétrico, sen tempo; se cando a foto comeza a fixar o seu vocabulario dende a noticia, a reportaxe, a ilustración gráfica ou a opinión editorial para diferentes modelos de prensa vai e fica sen lugar nen dereito de paso, agora sabemos que sempre haberá un declic que mire en dirección ao futuro, Pepe Sáez; un autor que rastrexe ese pequeno aletexo neorrealista, Manuel Ferrol; un fotoxornalista que no dea marcha atrás cando a vida se precipita directamente encol a película, Xosé Castro, ou alguén como Fernando Bellas que lle restitúa ao dispositivo o seu sentido.

\section{O nome das cousas}

Soamente cando nos alonxamos dalgo, nomeámolo. A frase que André Gide lle di a Benjamin en Berlín6, ce n'est qu'en quittant une chose que nous la nommons, após lembrar a do mariñeiro de Bougainville: ao abandonar a illa, démoslle o nome de Illa da Salvación, latexa neste retorno meu á fotoxornalismo en Galiza.

E para que a ausencia de Illa da Salvación ou da foto como foto non o fora tanto, voltamos os ollos para a inesgotábel mirada a cámara desa nena con veo que

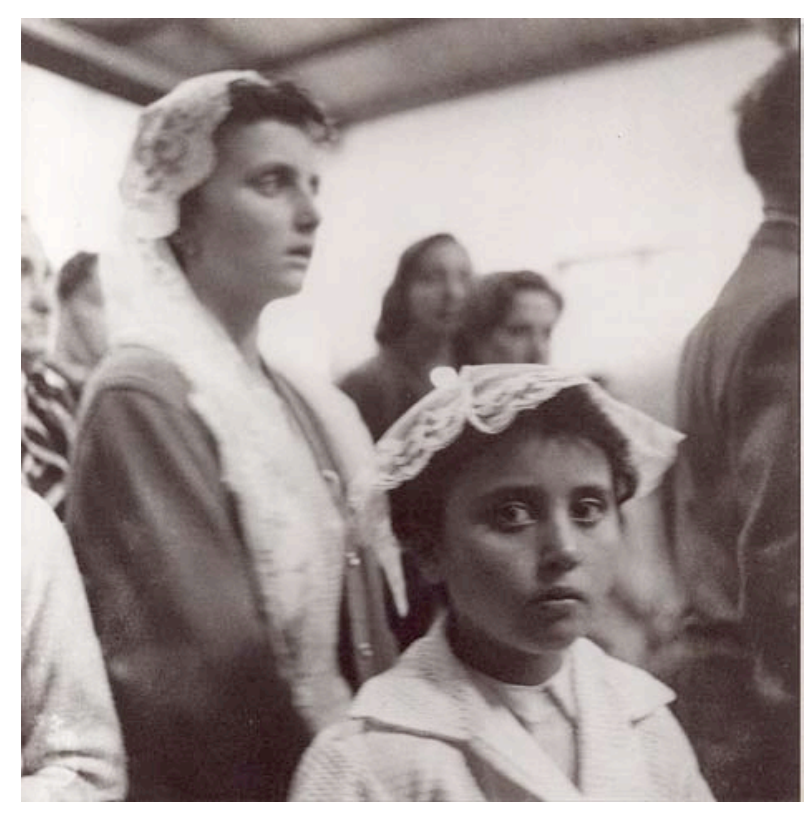
contradí a obriga de mirar para a fronte, que soborda ese espazo pechado e a súa condición migrante para ficar acó, no oco que abre para ela o déclic de Manolo Ferrol.

Emigración, Manuel Ferrol

\footnotetext{
${ }^{6}$ Véase Walter Benjamín, Imaginación y Sociedad, Iluminaciones I, Taurus, Madrid, 1998.
} 